\title{
Cross-Cultural Study of Korean Leadership in Indonesia By Using Kluckhohn-Strodbeck's Framework
}

\author{
Suharnomo $^{1^{*}}$ and Ndaru Risdanti ${ }^{2}$ \\ 1,2 Diponegoro University, Semarang, Indonesia
}

\begin{abstract}
The purpose of this paper is to investigate how South Korean expatriate manager interact with Indonesian subordinates and what the difference about their culture perspective in Semarang garment enterprises and identify how the difference of culture could affect their ability to manage staff and doing their job normally. A qualitative study was conducted. Triangulation methods are used to examine the validity of research data. The result indicated South Korean manager characteristics with Kluckhohn-Strodtbeck's dimension. There are contrast differences between South Korean manager with Indonesia employee in perception of time and space, which required adjustments in management practice for better performance results.
\end{abstract}

Keywords: Expatriate Manager, Leadership, National Culture, Organizational Culture

\section{INTRODUCTION}

From the very beginning there are three types of variable which commonly used to explain differences and similarities among management, are: economic, cultural, and psychological (Ajiferuke, 1970). It is a three variable which is connected and will be focus of most research done, moreover in the era of rapid industry and followed with massive globalization, which make the world become borderless. The companies nowadays will be compete to increase their competitiveness in many ways, one of them is make branch company in other country. With the rapid innovations such as telecommunications, new transport systems for both goods and people and internet the world has become globalized which has made it possible for companies to expand their business from the own country to other parts of the world (Hill, 2014). The idea to open a Branch Company in other countries, especially in countries that have many resources, both raw material and labor is to explore the new market and resource in order to reducing cost, more efficient production process, and economies of scale. Therefore, there are many Multi National Company (MNC), includes that came from South Korea, notice Indonesia as a potential country because of abundant natural resources and a huge market share, which quite interesting and profitable to make branch company in Indonesia.

Multi National Corporation (MNC) should have a lot of strategy to face globalization (Slavika et al.,(2015). Those strategy is very useful to increase product competitiveness, give a knowledge about international behavior, examine competitor's strategy, change of regulation of standart goal for manager who will

\footnotetext{
* Corresponding author. Email address: suharnomo.undip@gmail.com
} 
be promoted to expatriates. Expatriates is useful because managers will have a lot of experience with work domestic environment. Their success become a standart for promotion. International assignment become more important and being part of managerial career. As a consequences from this condition, leadership competition across culture is needed by company which operate in international market.

Relations between South Korea and Indonesia started since 1973 in areas such as political, economic, social, and cultural. With huge domestic market potential, a wealth of natural as well as human resources and stable economic growth in the range of $6 \%$ per year; Indonesia is one of the most attractive investment destinations. Meanwhile, the South Korean economy has grown rapidly with capital-intensive industries, high technology and skilled labor.

Due to certain year in the labor market, there are more than 2,200 companies South Korea has been in operation in Indonesia (Tempo Magazine, 2015). South Korean companies in Indonesia varied, ranging from world-class global companies like Samsung, LG, Hyundai, and small to medium-sized companies. ${ }^{1}$ South Korean companies in Indonesia employed around 500,000 workers in Indonesia, ranging from the level of director, manager up to the level of ordinary employees. The number of South Korean people who settled in Indonesia is plentiful, which are approximately 30,000 people.

According to Redding (1990) Employees' expectations, behaviour and performance may be different with various national cultures. Latham (2014) comes to a consistent conclusion that a universal answer on leadership does not exist. The influence of national culture on individual behaviour is well established and the differences are rather significant (Hofstede, 1980; Trompenaars and HampdenTurner, 1998). Within diversity culture that exist, the company must have an interaction of cross-cultural leadership among foreign managers (expatriates manager) and their local subordinates.

The differences in national cultures are reflected in how organisations are structured and managed (Chen, 2001). Because of that manager and subordinates need adaptation in order to cooperate. This interaction and cross-cultural leadership is somewhat interesting. Cross-cultural leadership research has largely been comparative research contrasting leadership styles of managers from different countries, for example the focus has been on understanding the differences and similarities across national cultures. The basic method for identifying such issues has been the use of quantitative questionnaire surveys. On the other hand, the implications of such cross-cultural differences in leadership inter action in multicultural settings has been clearly less studied (Suutari et al., 2002)

This study want to investigate how South Korean expatriate manager interact with Indonesian subordinates and what the difference about their culture perspective. This research was conducted in Multi National Company PT. Semarang Garment which is one of expansion company from Kukdong Corporation where based in Seoul, South Korea. The company has 2572 employees and led by a leader of South Korean citizen named Byun Hyo Su with other South Korea nationality managers and a number of local employees from Indonesia.

To fulfill the research objective, we first carried out the past literatures and build the conceptual framework. In section 3 we explain the methodology that used

\footnotetext{
${ }^{1}$ Famous south Korean brand in Indonesia (MillwardBrown report)
} 
to process the information obtained by depth interview with informants who was adjusted for purposes of research. In section 4 we give the result of this study and explain further in section 5 .

\section{LITERATURE STUDY}

\section{Past Research and Study}

Based on research conducted by Hofstede et al (2010), national cultural characteristic of South Korea, such as : 1) South Korean people thought some people more superior than others because of social status, gender, race, age, education, birth, attainment, background, and others; 2) South Korean people tended to uphold conformity and security; 3) People of South Korea prefered to avoid risk; 4) South Korean people always follow the formal rules and rituals that prevail in South Korea; 5) in South Korea, trust is only given to family and nearest friends; 6) South Korean society tended to accept power relationship which autocratic and paternalistic, subordinates know the power of others through formality, for example, the position of the hierarchy. This South Korea's national cultural criteria will vary with Indonesia national culture, although some dimension of culture between the two countries had in common because they are on large umbrella culture, the culture of Asia.

Table 1 Cultural Dimensions' Scores of Indonesia and South Korea

\begin{tabular}{lcccc}
\hline \multirow{2}{*}{\multicolumn{1}{c}{ Dimension }} & \multicolumn{2}{c}{ Indonesia } & \multicolumn{1}{c}{ South Korea } \\
\cline { 2 - 5 } & Score & Category & Score & Category \\
\hline Power Distance & 78 & Large PD & 60 & Large PD \\
Individualism vs. Collectivism & 14 & Collectivist & 18 & Collectivist \\
Masculinity vs. Femininity & 46 & Low Masculine & 39 & Low Masculine \\
Uncertainty Avoidance (UA) & 48 & Weak UA & 85 & High UA \\
\hline
\end{tabular}

Source: Hofstede, Hofstede, and Minkov (2010)

Differences in responses to various behaviours of leaders in different national cultures also investigated by Litrrell (2015) which observed manager from three different nationality, and investigate how national culture can affect behaviour. The differences among cultures also seen in research conducted by Pan, yue et al., (2010) who investigate the difference work-value among China and USA. Past research about interaction between expatriate manager with subordinates also done by Suutari et al., (2002) the research investigate interaction expatriate manager with Finnish nationality and Indonesian subordinates.

\section{Kluckhohn-Strodtbeck Value Orientation}

One theory of basic human values which has been very influential is Kluckhohn and Strodtbeck (1961). The cultural orientations framework was presented by Kluckhohn and Strodtbeck in their book Variations in Value Orientations (1961). The development of the theory, guided in part by Parsons and Shils (1951) general theory of action. Kluckhohnand Strodtbeck brings six dimensional value orientation which consists of the orientation of human nature, orientation of nature, time and space orientation, activities orientation, and relational orientation (Gudykunstand and Kim, 1997). Kluckhohn and Strodtbeck (1961) compared the culture based on several dimensions. The first dimension is 
orientation of human nature associated with traits. In this dimension, human beings are good or bad or a mixture of good and bad, which decides since birth. The second dimension, orientation of human relationships and nature. There are three types of relationships namely subdued, align, and control. The third dimension, time orientation. In this dimension, human life can be focused on the past, present, or future. The fourth dimension, orientation activities. According to KluckhohnStrodtbeck, the orientation to the activity could be seen as doing, being, and being in becoming. The fifth dimension, relational orientation, associated with individualism-collectivism dimension, and the sixth dimension are the conception of space.

Table 2 Kluckhohn and Strodtbeck Dimensions

\begin{tabular}{|c|c|c|}
\hline No. & Dimension & Indicators \\
\hline I & Nature of humans & $\begin{array}{l}\text { - Good/Bad: The basic nature of people is } \\
\text { essentially good (lower score) or evil (higher } \\
\text { score). } \\
\text { - Changeable/Unchangeable: The basic nature of } \\
\text { humans is changeable (higher score) from good } \\
\text { to evil or vice versa, or not changeable (lower } \\
\text { score). }\end{array}$ \\
\hline II & $\begin{array}{l}\text { Relationships among } \\
\text { people / focus } \\
\text { responsibility }\end{array}$ & $\begin{array}{l}\text { - Individual: Our primary responsibility is to and } \\
\text { for ourselves as individuals, and next for our } \\
\text { immediate families. } \\
\text { - Collective: Our primary responsibility is to and } \\
\text { for a larger extended group of people, such as an } \\
\text { extended family or society. } \\
\text { - Hierarchical: Power and responsibility are } \\
\text { naturally unequally distributed throughout } \\
\text { society; those higher in the hierarchy have power } \\
\text { over and responsibility for those lower. }\end{array}$ \\
\hline III & $\begin{array}{l}\text { Relation to broad } \\
\text { environment }\end{array}$ & $\begin{array}{l}\text { - Mastery: We should control, direct and change } \\
\text { the environment around us. } \\
\text { - Subjugation: We should not try to change the } \\
\text { basic direction of the broader environment } \\
\text { around us, and we should allow ourselves to be } \\
\text { influenced by a larger natural or supernatural } \\
\text { element. } \\
\text { - Harmony: We should strive to maintain a } \\
\text { balance among the elements of the environment, } \\
\text { including ourselves. }\end{array}$ \\
\hline IV & Activity & $\begin{array}{l}\text { - Doing: People should continually engage in } \\
\text { activity to accomplish tangible tasks. } \\
\text { - Thinking: People should consider all aspects of a } \\
\text { situation carefully and rationally before taking } \\
\text { action. } \\
\text { - Being: People should be spontaneous, and do } \\
\text { everything in its own time. }\end{array}$ \\
\hline
\end{tabular}




\begin{tabular}{lcl}
\hline No. $\quad$ Dimension & \multicolumn{1}{c}{ Indicators } \\
\hline & & - Past: Our decision criteria should be guided \\
& mostly by tradition. \\
& & Present: Our decision criteria should be guided \\
& mostly by immediate needs and circumstances. \\
V & Future: Our decision criteria should be guided by \\
& predicted long term future needs and \\
& circumstances. \\
& & Public: The space around someone belongs to \\
& & everyone and may be used by everyone. \\
& & Private: The space around someone belongs to \\
& & that person and cannot be used by anyone else \\
VI & without permission.
\end{tabular}

Source: Kluckhohn, F. R. \& Strodtbeck, F. L. (1961)

This research want to finding more about how the two culture interact each other, in this case South Korean nationality is the manager, and Indonesia Nationality as the subordinates, this research will be limited by the dimensions of the cultural framework Kluckhohn and Strodtbeck. The sixth dimension will be used to analyze the leadership style of South Korean managers with South Korean national cultural backgrounds, and how the local community (Indonesian culture) contrast with the leadership of the South Korean culture in Indonesia.

\section{Research Framework. Cross-Cultural Study Of Korean Leadership In Indonesia By Using Kluckhohn-Strodbeck's Framework}

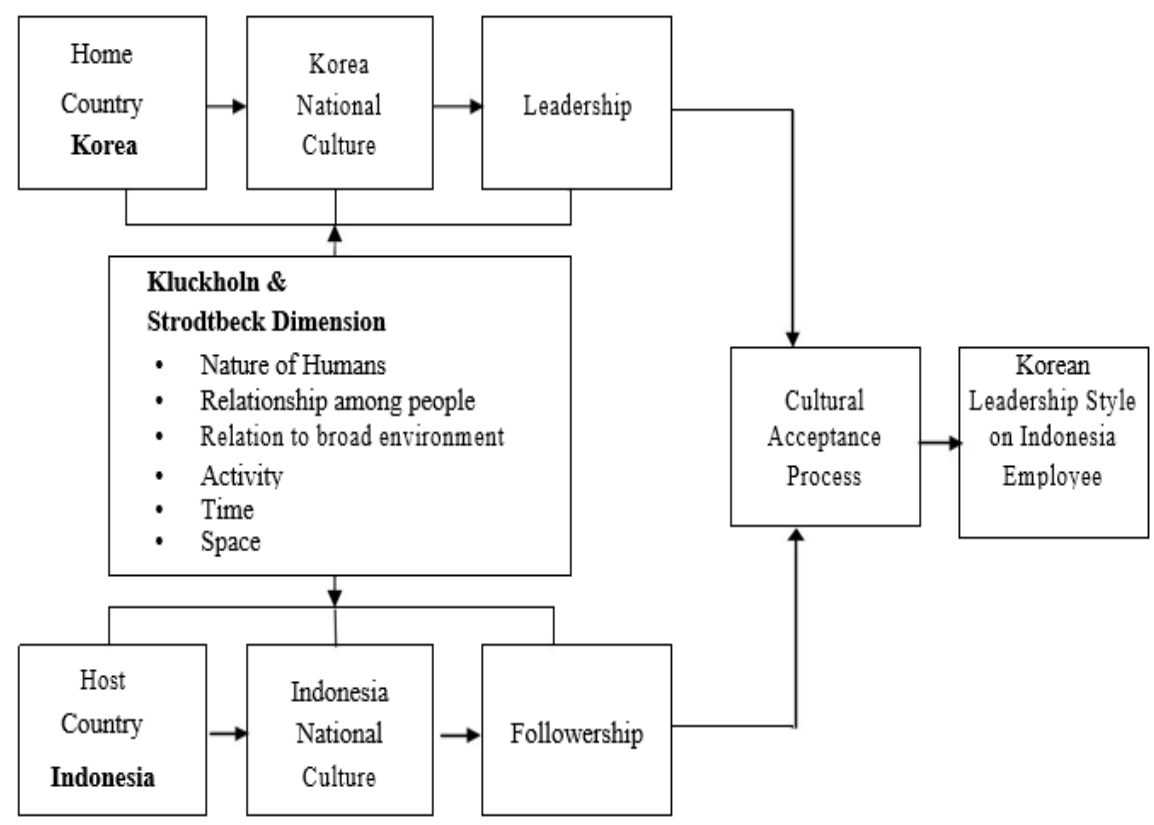




\section{RESEARCH METHODOLOGY}

This research is a qualitative, method used was triangulation where opinions of different informants confronted to see the essence of what is being studied. According to Moleong (2007) a form of triangulation utilizing data validity checking something else beyond the data for the purpose of checking or as a comparison against the data. Information obtained from depth interviews with informants who was adjusted for purposes of research. In depth interviews on qualitative research take a long time and many details, so the sample used typically limited, only understood informants and involved in the issues are used. Triangulation methods are done in three ways, as follows; interviews, direct observation and indirect observation. Indirect observation is intended to observe some of the studies in order to obtain ease in finding represents a connection between the events. Data collection techniques used to complement the primary and secondary data obtained. Observations and interviews used to collect primary data relating to the South Korean style of leadership in Indonesia.

The number of participants in this study are three South Korea nationality managers, seven supportive informant who is local (Indonesian nationality) people and have worked there for at least five years. Getting focus to the appropriate key informant research, the informant selected by using purposive sampling (sampling in accordance needs). The basis of a sample is South Korean expatriate managers and Indonesia local employees at PT. Garment Indonesia Semarang which understand leadership, often interact with or feel leadership directly, already working in PT. Garment Semarang Indonesia for a minimum three years, and can speak or answer interview accurately.

Table 3 Respondent List

\begin{tabular}{|c|c|c|c|c|}
\hline Code & Respondent Name & Department & Work Time & Nationality \\
\hline $\mathrm{R} 1$ & $\begin{array}{l}\text { Kim Hak Hee (Richard } \\
\text { Kim) }\end{array}$ & $\begin{array}{l}\text { Manager of Factory I } \\
\text { General Manager } \\
\text { Accounting Manager }\end{array}$ & 5 year & South Korea \\
\hline R2 & Byun Sang In & Export-Import Manager & 10 year & South Korea \\
\hline R3 & Park Tae Seon & Finishing Manager & 10 year & South Korea \\
\hline R4 & Tri J. & Labor Concern Manager & 5 year & Indonesia \\
\hline R5 & Ambar & Sample Chief & 5 year & Indonesia \\
\hline R6 & Hernowo & Finishing Chief & 8 year & Indonesia \\
\hline R7 & Endang $\mathrm{S}$. & Worker & 5 year & Indonesia \\
\hline R8 & Winarni & Worker & 6 year & Indonesia \\
\hline R9 & Rini & Cleaning service & 10 year & Indonesia \\
\hline $\mathrm{R} 10$ & Hertanto & Security & 10 year & Indonesia \\
\hline
\end{tabular}

Source: Research Data (2016)

\section{Procedure}

Face to face interviews were held. Each informant or respondent had given participation form and was later contacted to confirm their participation. Participants were advised that it was intended that their interviews would be voiced recorded to aid transcription. Obtained information from interviews generally formed statement, which described the experience, knowledge, opinions and personal feelings. For obtaining this data, researchers used a Scheduled 
Standardized Interview and informal interview. The three approaches can be done with technique as follows: (A) Before the interview begins, introduce ourselves politely to create a good relationship. (B) Showed respondents that they looked as "important".

Exploring as much as possible. (D) No makes certain direction answer to informant. (E) Repeating questions if necessary. (F) Clarify answers. (G) Record the interview (Chariri, 2007).

\section{RESULTS}

In examining the validity of research data using triangulation techniques. According to Moleong (2007) a form of triangulation utilizing data validity checking something else beyond the data for the purpose of checking or as a comparison against the data. Denzin (1978) in Moleong (2007) distinguished four types of triangulation as a technical inspection or checking of the validity of the data that utilizes the use of sources, methods, investigators, and the supporting theory. In this study, triangulation using source type where the informants from different backgrounds are given the opportunity to give an opinion on the same issue. Researchers conclude whether essentially, a statement in the research confirmed or not from different infomants.

Table 4 Result Analysis About South Korean Style Leadership Based On Cultural Dimensions by Kluchkhon \& Strodtbeck: Triangulation based on Sources

\begin{tabular}{|c|c|c|c|c|}
\hline No & Dimension & $\begin{array}{c}\text { South Korean } \\
\text { Employee's } \\
\text { Perspective }\end{array}$ & $\begin{array}{l}\text { Indonesian } \\
\text { Employee's } \\
\text { Perspective }\end{array}$ & Triangulation \\
\hline 1. & Nature of humans & $\begin{array}{l}\mathrm{R} 1, \mathrm{R} 2 \text { and R3 states } \\
\text { that the South Korean } \\
\text { manager believes the } \\
\text { two kind of character; } \\
\text { good and bad in man } \\
\text { (the basic human } \\
\text { characters). } \\
\text { "The philosophy in our } \\
\text { country, there are two } \\
\text { kind of characters of } \\
\text { human which are good } \\
\text { and bad. Basically } \\
\text { human being is born } \\
\text { the same. But how do } \\
\text { they grow, it's } \\
\text { depending on their } \\
\text { surrounding, their } \\
\text { education from home, } \\
\text { school and society that } \\
\text { determine what kind of }\end{array}$ & $\begin{array}{l}\text { This value justified or } \\
\text { validated by a } \\
\text { statement by R4, R5 } \\
\text { and R6. } \\
\\
\text { “I know less about the } \\
\text { Korean people's views } \\
\text { on this. But I know they } \\
\text { believe the teaching of } \\
\text { the Chinese yin-yang, } \\
\text { there is a good } \\
\text { character (positive) } \\
\text { and a bad character } \\
\text { (negative).” (R4) }\end{array}$ & $\begin{array}{l}\text { There are both good } \\
\text { and bad in people. All } \\
\text { informants provide a } \\
\text { matching statement } \\
\text { that there are good and } \\
\text { bad sides of human and } \\
\text { many factors that can } \\
\text { influence people to be } \\
\text { good or bad. }\end{array}$ \\
\hline
\end{tabular}




\begin{tabular}{|c|c|c|c|c|}
\hline No & Dimension & $\begin{array}{c}\text { South Korean } \\
\text { Employee's } \\
\text { Perspective }\end{array}$ & $\begin{array}{l}\text { Indonesian } \\
\text { Employee's } \\
\text { Perspective }\end{array}$ & Triangulation \\
\hline & & $\begin{array}{l}\text { person he will be." } \\
\text { (R1) }\end{array}$ & & \\
\hline 2. & $\begin{array}{c}\text { Focus } \\
\text { responsibility }\end{array}$ & 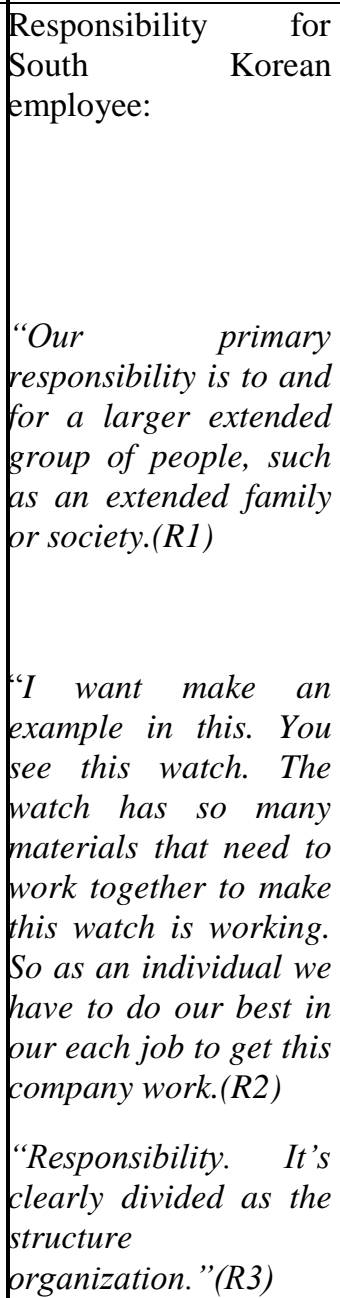 & $\begin{array}{l}\text { Indonesia Informants, } \\
\mathrm{R} 4, \mathrm{R} 5, \mathrm{R} 6, \mathrm{R} 7 \text { and } \mathrm{R} 8 \\
\text { also agree on what the } \\
\text { collective feeling. } \\
\\
\text { “Responsibilities are } \\
\text { divided based on their } \\
\text { position within the } \\
\text { company and } \\
\text { everyone holds their } \\
\text { respective roles for } \\
\text { the survival of the } \\
\text { company."(R5) } \\
\text { "Responsibility must } \\
\text { be done. Koreans are } \\
\text { quite a responsibility } \\
\text { to his } \\
\text { subordinates."(R7) }\end{array}$ & $\begin{array}{l}\text { Among the three } \\
\text { options, as follow: } \\
\text { individual, collective } \\
\text { and hierarchical, South } \\
\text { Korea manager that R1, } \\
\text { R2 and R3 tend to } \\
\text { choose collective. } \\
\text { Statement of R1, R2 } \\
\text { and R3 leads to } \\
\text { character of South } \\
\text { Korean managers who } \\
\text { focus on collective } \\
\text { responsibility validated } \\
\text { by the statement of R4, } \\
\text { R5, R6, R7 and R8. }\end{array}$ \\
\hline 3. & $\begin{array}{l}\text { Relation to } \\
\text { broad } \\
\text { environment }\end{array}$ & $\begin{array}{l}\text { "We need to live in } \\
\text { harmony with the } \\
\text { environment. In my } \\
\text { opinion, our company } \\
\text { manage everything } \\
\text { quiet well related with } \\
\text { the environment and } \\
\text { also the surrounding. } \\
\text { It shows that the }\end{array}$ & $\begin{array}{l}\text { "Company relation } \\
\text { with surrounding } \\
\text { environment work } \\
\text { well. } \\
\text { employees also come } \\
\text { from around here. } \\
(R 4)\end{array}$ & $\begin{array}{l}\text { There are three } \\
\text { tendencies which is } \\
\text { mastery, subjugation } \\
\text { or harmony. South } \\
\text { Korea employees } \\
\text { choose harmony: We } \\
\text { should strive to } \\
\text { maintain a balance } \\
\text { among the elements of }\end{array}$ \\
\hline
\end{tabular}




\begin{tabular}{|c|c|c|c|c|}
\hline No & Dimension & $\begin{array}{c}\text { South Korean } \\
\text { Employee's } \\
\text { Perspective }\end{array}$ & $\begin{array}{l}\text { Indonesian } \\
\text { Employee's } \\
\text { Perspective }\end{array}$ & Triangulation \\
\hline & & $\begin{array}{l}\text { surrounding do not } \\
\text { complain about the } \\
\text { factory activity."(R1) } \\
\text { "We must protect our } \\
\text { environment. The } \\
\text { environment should } \\
\text { remain good so that } \\
\text { we may live } \\
\text { comfortably in the } \\
\text { world. Factory we } \\
\text { already had an } \\
\text { environmentally } \\
\text { friendly } \\
\text { management." (R2) }\end{array}$ & $\begin{array}{l}\text { Factory activity not } \\
\text { to interfere with the } \\
\text { public. Also working } \\
\text { hours } 7 \text { am to } 4 \text { pm." } \\
\text { (R5) } \\
\text { "Sewage treatment } \\
\text { management and } \\
\text { disposal system in } \\
\text { this factory is good } \\
\text { enough and does not } \\
\text { harm the } \\
\text { surrounding community." (R7) } \\
\text { comm the }\end{array}$ & $\begin{array}{l}\text { the environment, } \\
\text { including ourselves. }\end{array}$ \\
\hline 4. & Activity & $\begin{array}{l}\text { "We need to consider } \\
\text { many things in acting } \\
\text { or doing something. } \\
\text { But continued to run } \\
\text { the things we should } \\
\text { do."(R2) } \\
\text { should be } \\
\text { Work ampleted as a part of } \\
\text { come responsibilities of } \\
\text { each. Think before act } \\
\text { but don't wait too } \\
\text { long."(R3) }\end{array}$ & $\begin{array}{l}\text { "I saw my boss } \\
\text { (manager) tried to do } \\
\text { everything carefully } \\
\text { (thoughtful) but they } \\
\text { are quick to } \\
\text { act."(R5) }\end{array}$ & $\begin{array}{l}\text { Among the selection } \\
\text { of doing, thinking and } \\
\text { being, thinking } \\
\text { considered } \\
\text { informants in every } \\
\text { aspect in making the } \\
\text { decision. They act by } \\
\text { considering } \\
\text { everything would be } \\
\text { done but chose to act } \\
\text { quickly. }\end{array}$ \\
\hline 5. & Time & $\begin{array}{l}\text { "Of course we believe } \\
\text { our past and want to } \\
\text { keep our tradition } \\
\text { until now. But the } \\
\text { young generations } \\
\text { now get a lot } \\
\text { influenced by western } \\
\text { culture. Korea have }\end{array}$ & $\begin{array}{l}\text { "They really } \\
\text { appreciate the time. } \\
\text { Loyalty at work is } \\
\text { very high. One time } \\
\text { there is one manager } \\
\text { sick should infuse } \\
\text { and two hour rest in } \\
\text { the mess but }\end{array}$ & $\begin{array}{l}\text { Statement of R1, R2 } \\
\text { and R3 leads to a time } \\
\text { dimension that shows } \\
\text { the character of South } \\
\text { Korean managers are } \\
\text { very concerned past } \\
\text { and appreciate every } \\
\text { time owned. But also }\end{array}$ \\
\hline
\end{tabular}




\begin{tabular}{|c|c|c|c|c|}
\hline No & Dimension & $\begin{array}{c}\text { South Korean } \\
\text { Employee's } \\
\text { Perspective }\end{array}$ & $\begin{array}{l}\text { Indonesian } \\
\text { Employee's } \\
\text { Perspective }\end{array}$ & Triangulation \\
\hline & & $\begin{array}{l}5000 \text { years history. } \\
\text { Also history of each } \\
\text { family is important for } \\
\text { us."(RI) } \\
\text { "Past made what we } \\
\text { are now. The present } \\
\text { (now) made what we } \\
\text { are in the future. I will } \\
\text { keep my tradition } \\
\text { from the past (of my } \\
\text { country) to work in } \\
\text { everywhere even it is } \\
\text { abroad."(R2) } \\
\text { "Working hours in } \\
\text { Korea longer than } \\
\text { Indonesia. Our habit } \\
\text { of working quickly } \\
\text { with good } \\
\text { results."(R3) }\end{array}$ & $\begin{array}{l}\text { surprising after that } \\
\text { he kept returning to } \\
\text { work at the factory." } \\
\text { (R5) } \\
\text { "The manager had } \\
\text { told me, in Korea if a } \\
\text { woman should give } \\
\text { birth even to keep } \\
\text { working until the } \\
\text { time came to give } \\
\text { birth and then was } \\
\text { taken to hospital, but } \\
\text { three hours after } \\
\text { birth they are ready } \\
\text { to return to work." } \\
\text { (R6) }\end{array}$ & $\begin{array}{l}\text { think about the future, } \\
\text { not stuck in the past. }\end{array}$ \\
\hline \multirow[t]{2}{*}{6.} & \multirow[t]{2}{*}{ Space } & $\begin{array}{l}\text { "I love the private } \\
\text { rooms. But my room } \\
\text { here was enough for } \\
\text { me. I fused with other } \\
\text { workers." (R2) }\end{array}$ & $\begin{array}{l}\text { "The managers of } \\
\text { Korea tend to be } \\
\text { serious at work and } \\
\text { chose to limit } \\
\text { themselves } \\
\text { employees." (R6) }\end{array}$ & $\begin{array}{l}\text { Statement of R1, R2 } \\
\text { and R3 lead to spatial } \\
\text { dimensions show South } \\
\text { Korean managers } \\
\text { prefer private than } \\
\text { public. }\end{array}$ \\
\hline & & $\begin{array}{l}\text { "There are certain } \\
\text { spaces that are specific } \\
\text { to the boss and } \\
\text { forbidden to be entered } \\
\text { by employees without } \\
\text { permission in advance } \\
\text { to the manager." (R4) }\end{array}$ & & \\
\hline
\end{tabular}

Source: Research Analysis (2016)

\section{DISCUSSION}

Based on previous analysis has known South Korean leadership character style applied to the PT. Semarang Garment accordance with the dimensions restricted this research, which is cultural dimensions of Kluckhohn and 
Strodtbeck's. In general, South Korean culture is part of the Eastern culture so that the character of the leadership style being applied is not difficult to be followed by local employees in the company.

The results showed the character of the South Korean style of leadership in Indonesia, especially at PT. Garment Semarang. It is beneficial for the company if they can manage their local cultural differences with the South Korean leadership style where the company has an array of managers and leaders from South Korea, especially South Korea and local employees who were mostly residents of Central Java ${ }^{2}$.

\section{a. Nature of humans}

South Korean culture tends to see human has two different character in themselves, good and bad. This determines their characteristic in relation with other people. Surely, they will be careful in relation with other people. "Each people has each characteristic. Some of them learn quickly. Some of them are doing something slowly. Some are good some are not good. The first two years I worked here, often found employees who often late, not fast, slowly learning, not working, and I got a lot of headache because of that. However, in current condition I am not really headache and stressful anymore. They become more skillful." (R1). In addition, they also considered the Indonesian people are very nice and friendly and make strangers as they feel comfortable and appreciated by employees. (R1, R2, R3).

Most of South Korean managers believe that good environment could create someone grow better than before. Based of fact, they will try to make good environment such as discipline, diligent and work hard in company in purpose to be followed by the local employees. Both Korean and Indonesian cultures realized that human behavior could be classified into categories of good and bad. Therefore, there are relatively no cultural barriers to make the employee management program to achieve superior performance.

\section{b. Focus responsibility}

Result analysis of focus responsibility proved that South Korean managers apply leadership character that upheld responsibility for other people such as responsibility as a group. This related to their performance which aware of quality of cooperation and had work between employee to fulfill and actualize company target. In Kluckhohn and Strodbeck (1961) dimension, South Korean tends to choose a collectively means the division of work and responsibility very prioritized.

This value is equal to the culture of 'gotong-royong' ${ }^{\prime 3}$ in Indonesia where heavy work can be done together and help each other to complete. In the perspective of the cultural dimensions of Hofstede et al., (2010), the two nations are also included under the category of collective and equally high power distance. Compared to Korea, Indonesia has particularly higher power distance, therefore ideals for employees is very important for Indonesia employees. The leader has

\footnotetext{
${ }^{2}$ Central Java is a capital of the Java province in Indonesia

3 'Gotong Royong' or known as communal work in English. 'Gotong Royong' is a form of action usually done by several groups of people achieve shared objective. In the context of Indonesia, the culture of 'Gotong Royong' is usually comes as a communal value and has become a culture of people. For example, farmers usually work together for the irrigation of their rice field, or the neighbourhood helping each other if there is natural disaster.
} 
incredible power that instantiate into practice in daily life, Indonesian employee quickly adjust themselves according to the requirements of the behavior and performance of the company.

\section{c. Relation to broad environment}

South Korean manager character has a same view with east culture in general, which is always will to live in harmony with nature and environment. This will help and ease interaction of company and environment because with good management to the environment will minimize conflict with nearly society environment and do not disturb nature. This character is positively good either to company or nearly company environment.

South Korea manager is not a person who can work in spontaneity situations (being), but familiar in planned work with consider of many aspects (thinking). Koreans also considers many things before making management decisions. These values are the same as the value of the employee Indonesia. Indonesia has thousands of ethnic nation and the local language thousands of species as well. Therefore, the Indonesian people familiar with the pattern of decision making that considers many aspects to maintain harmony. Harmony is necessitated both by South Korean managers and employees Indonesia. Employees Indonesia even really appreciated events and religious customs.

d. Activity

In case decided an action, South Korean managers tend to consider multi aspects that related with the action. Considering first before action is one of South Korean manager character, but it does not create them slow in respond. All aspects considered deeply, and fast action implemented. This thing is all good for the company.

Eastern culture generally preferred harmony. In fact, in many instances tend to lead to subjugation. Harmony with man and nature became a choice for most East people. The religious ceremonies and customs are also often done to show respect for people, nature and the $\mathrm{x}$-factor in life. X Factor for Eastern nations is the extra power beyond the physical but very influential on the work conditions and the results of the company's performance. Most convictions are the hope in God, others more confident with the spirit of animism or dynamism. The activities are a form of gratitude or belief procession is expected to do in the company. The event usually used for meeting and discussing a lot of things, especially about family and social life.

e. Time

Leadership South Korean characteristic has high appreciation for the time, where they utilize every single second properly especially to work as their principle such as work hard to get anything better. Moreover, they also uphold firmly to the past, so they still maintain tradition and culture from their country that has east culture and local customs. This does not make them shackled by the past, but this tradition which upheld by South Korean people brought them to good behavior suited east culture and good future planning also considered well. Based on that criteria, affection that given by South Korean managers will sense positively to the company environment and ease the cooperation with the local employees. However South Korean time perspective seen contrast difference with Indonesia time perspective. Indonesia is categorized as Polychronic, means used to think and do a lot of activities in the same time. The remaining time is often not used for the perfection of the work but used for another job (which sometimes are not related 
to the achievement of company performance) or conducting a particular form of hobby or pleasure.

"The first two years I worked here I often found employees who often late, not fast, slowly learning, not working. And I got a lot of headache because of that. However, now, i am not really headache and stressful anymore. They become more skillful." That is, the statement of Korean Manager. Another experience is also delivered by Korean managers how about the perception of use time in vain. "Do you know the sentences jam karet Indonesia?" that exactly often happen. In Korea when working, our boss will tell to do it faster and faster. But in here, they take it easy, they think there is still tomorrow to do the job." According to the manager, habits of Indonesia employee are often delays their job, so it seems a long time to work. For them if there is time remaining, they can use them for other jobs or get some rest if nothing else is done.

Other differences regarding high uncertainty avoidance feeling for Koreans. Uncertainty Avoidance Hofstede version of the Korean nation is very high (85) so that the future was met with anxiety and heightened alertness. Time is very important and not repetitive, so they do work hard and often beyond normal human strength. In the case of the use of time, there is a contrast difference between the Korean employee and the Indonesian employee. In polychronic society perspective, as if time spinning where there is always a hazy day to finish the unfinished job. Therefore, need to be made of company regulations that could accommodate both. Strict rules need to be made although some social interests also need to be considered.

\section{f. Space}

Space can be interpreted in the perspective of physical and strata. South Korean managers character want a private space for themselves and not disturbed by other employee. In a society with a high power distance as Korea and Indonesia, the position of the space and design in the space, are to mirror the difference in social strata. Social strata do exist though starting to shift from the group known as the patrician shifts, toward a society where the highest social class is occupied by a group that has the highest achievement.

"Different class of society does exist. Every person has a history and has a tree of family. It's very wide cases. I can't say it in a word. Long time ago, we have something like that. Kim family, Choi family, for example, is famous as the rich family. It was very common. Some name seen as rich families, some name seen as lower social class by the society. But nowadays, they are judged by the achievement they got. We have to see the people from the higher class so that we able to try harder and work harder for someday to be one of them. I think class of society in every part of the world does exist, even in America or in Indonesia." Thus the explanation R1, Korean Manager. The statement strenghten by the only Indonesia Manager which charge and human resources as follows:

"I've heard from my boss that there are social classifications in Korea. The name "Kim" is a name known to wealthy families as well as other names with different social classes. Garment Semarang company owner did not come from a family with the name and background are respected. "Byun" is the name of the social classes were quite down but hard work from young until he became the honorable man today".

Based on the justification of the above, it can be said that the character profile Korean manager still saw someone based on its position in the social classes. It is 
common in South Korea. The family name given by his family history is seen as a wealthy family and has influence in Korea. There is also another name with a particular social class. However, as time goes by and the times it can be said that the ascriptive views of Korean began shift to a view with achievement orientation. No doubt if the name of a family is still seen and has value to them, but the achievement of a person become successful also make the person is respected in South Korea. Condition in PT Semarang Garment showed that several manager rooms merged with other employees without any borders. This condition makes them change a perspective about private space and adapt with condition and environment of company.

\section{CONCLUSIONS}

Indonesian culture have many similarities with South Korean culture, based on that the South Korean manager in Semarang Garment can adapted with the culture of local subordinates, seen from the satisfaction of the manager, who did not experience any difficulties, except in the early days of their arrival only. Open mind and courteous attitude that Indonesian employees have greatly assisted the process of adaptation of the Korean managers in adjusting to some aspects of the cultural values that differ especially in terms perspective of time and space.

However, this study only took the object of research on the multi-national companies of South Korea in Indonesia as well as limited by the cultural dimensions of Kluckhohn-Strodtbeck's. The theory of South Korea's leadership style can be supported by other national cultural theories as well, which supports the depth of research. Based on the result from this future study research is expected to examine the South Korean style of leadership in several multi-national companies of South Korea in Indonesia to complete the justification of the cultural characteristics and leadership style of South Korea.

Based on previous analysis, discover that South Korean leadership style characters which applied to the PT. Semarang Garment, mostly suitable with the dimensions of Indonesian culture. In general, South Korean culture is part of the Eastern culture so that the character of leadership style being applied is not difficult to follow by local employees of the company. In terms of perspective to time and place, the two cultures there are contrast different and thus require adjustments, such as the company can make strict rules regarding matter of time and discipline, and held meeting and discussion with manager and employee representation, to discuss about discipline and how they want to be treated.

\section{References}

Ajiferuke, M., \& Boddewyn, J J. (1970). Culture and Other Explanatory Variables in Comparative Management Studies. Academy of Management Journal, 13, 153-163. http://www.jstor.org/stable/255102.

Chariri., \& Ghozali, A. (2007). Teori Akuntansi. Semarang : Badan Penerbit Undip. ISBN : 979.704.014.3 
Chen, M. (2001). Asian Management Systems. London: Thomson. ISBN : 9781861529411

Dewimerdeka, M. K. (2015). 2.200 Perusahaan Korsel Beroperasi di Indonesia, TEMPO.

Fukushige, A., \& Spicer, D. P. (2006). Leadership Preferences in Japan: an Exploratory Study. Leadership and Organizational Development Journal, $28 \quad$ (6), 508-530. http://dx.doi.org/10.1108/01437730710780967.

Gudykunst, W. B., \& Kim, Y. Y. (1997). Communicating with strangers: An approach to intercultural communication (3rd Ed.). New York: McGrawHill. ISBN-13: 978-0070346475

Hill C. (2014). International Business: Competing in the Global Marketplace (10th edition). McGrawHill Education, New York. ISBN-13: 978-0078112775. https://doi.org/10.5937/ekonhor1501073g

Kluckhohn, F. R., \& Strodtbeck, F. L. (1961). Variations in Value Orientations. Evanston, IL: Row, Peterson. ISBN : 978-0-9845627-0-1. https://doi.org/10.2307/480364

Latham, J. R. (2014). Leadership for Quality and Innovation: Challenges, Theories, and a Framework for Future Research. Quality Management Journal [online]. 21 (1), 11-15 [cit. 2014-08-19]. Dostupne z: http://web.a.ebscohost.com.ezproxy.lib.vutbr.cz/ehost/detail/detail?vid=1 4\&sid=161530e5-b027-4963-b687-

Littrel, R. F. (2005). Preferred Leadership Behaviours: Exploratory Results from Romania, Germany, and the UK. Journal of Management Development, $24 \quad$ (5), 421-442. http://dx.doi.org/10.1108/02621710510598445.

Moleong, L. J. (2007). Metodologi Penelitian Kualitatif. Bandung: PT. Remaja Rosdakarya. ISBN : 979-514-051-5.

Pan, Yue et al. (2010). A Cross-cultural Investigation of Work Values among Young Excecutives in China and the USA. Cross Cultural Management: An Internasional Journal, $17 \quad$ (3), 283-298. http://dx.doi.org/10.1108/13527601011068379.

Parsons, T., \& Shils, E.A. (1951). Toward a General Theory of Action. Cambridge, MA:Harvard University Press. ISBN 9780674863507.https://doi.org/10.4159/harvard.9780674863507

Rachel, K. (2004). Culture, intercultural communication competence, and sales negotiation: a qualitative research approach. Journal of Business \& $\begin{array}{lcc}\text { Industrial } & \text { Marketing, } & 19 \\ \text { http://dx.doi.org/10.1108/08858620410516745. }\end{array}$ 
Redding, G. (1990). The Spirit of Chinese Capitalism. Walter de Gruyter. New York.

ISBN 978-3-11-088770-9. https://doi.org/10.1515/9783110887709

Robbins, S. P., \& Judge, T. A. (2008). Organizational Behaviour. Upper Saddle River, N.J: Pearson/Prentice Hall. ISBN 13 : 978-0-13-283487-2

Slavika et al. (2015). Leadership as a tool of strategic management. Procedia Economics and Finance, 26, 1159 - 1163. doi: 10.1016/S22125671(15)00946-6

Suutari, Vesa et al. (2002). The Challenge of Cross-cultural Leadership Interaction: Finnish Expatriates in International, 7 Indonesia.

Career Development http://dx.doi.org/10.1108/13620430210449948. 